\title{
Challenges in Developing Adaptive Educational Hypermedia Systems
}

\author{
Eileen O'Donnell \\ Technological University Dublin, eileen.odonnell@TUDublin.ie \\ Liam O'Donnell \\ Technological University Dublin, liam.odonnell@tudublin.ie
}

Follow this and additional works at: https://arrow.tudublin.ie/buschmanbk

Part of the Educational Methods Commons

\section{Recommended Citation}

O'Donnell, E. and O'Donnell, L. (2017) Challenges in developing Adaptive Educational Hypermedia Systems. In Encyclopedia of Information Science and Technology, Fourth Edition, Information Resources Management Association (IRMA).

This Book Chapter is brought to you for free and open access by the School of Management at ARROW@TU Dublin. It has been accepted for inclusion in Books/Book Chapters by an authorized administrator of ARROW@TU Dublin. For more information, please contact arrow.admin@tudublin.ie, aisling.coyne@tudublin.ie, gerard.connolly@tudublin.ie.

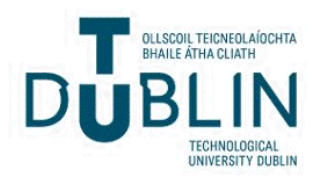




\section{Encyclopedia of Information Science and Technology, Fourth Edition}

Mehdi Khosrow-Pour, D.B.A.

Information Resources Management Association, USA

Volume III

Categories: CU - ED 
Published in the United States of America by

IGI Global

Information Science Reference (an imprint of IGI Global)

701 E. Chocolate Avenue

Hershey PA, USA 17033

Tel: 717-533-8845

Fax: 717-533-8661

E-mail: cust@igi-global.com

Web site: http://www.igi-global.com

Copyright ( 2018 by IGI Global. All rights reserved. No part of this publication may be reproduced, stored or distributed in any form or by any means, electronic or mechanical, including photocopying, without written permission from the publisher. Product or company names used in this set are for identification purposes only. Inclusion of the names of the products or companies does not indicate a claim of ownership by IGI Global of the trademark or registered trademark.

Library of Congress Cataloging-in-Publication Data

Names: Khosrow-Pour, Mehdi, 1951- editor.

Title: Encyclopedia of information science and technology / Mehdi

Khosrow-Pour, editor.

Description: Fourth edition. I Hershey, PA : Information Science Reference,

[2018] I Includes bibliographical references and index.

Identifiers: LCCN 2017000834| ISBN 9781522522553 (set : hardcover) | ISBN

9781522522560 (ebook)

Subjects: LCSH: Information science--Encyclopedias. I Information

technology--Encyclopedias.

Classification: LCC Z1006 .E566 2018 I DDC 020.3--dc23 LC record available at https://lccn.loc.gov/2017000834

British Cataloguing in Publication Data

A Cataloguing in Publication record for this book is available from the British Library.

All work contributed to this book is new, previously-unpublished material. The views expressed in this book are those of the authors, but not necessarily of the publisher.

For electronic access to this publication, please contact: eresources@igi-global.com. 


\section{Challenges in Developing Adaptive Educational Hypermedia Systems}

\author{
Eileen O'Donnell \\ Trinity College Dublin, Ireland \\ Liam O'Donnell \\ Dublin Institute of Technology, Ireland
}

\section{INTRODUCTION}

Traditional educational hypermedia systems afford learners the "one size fits all" approach to learning (Brusilovsky, 2003, 2004; Chatti, Jarke, \& Specht, 2010; Hsieh, Lee, \& Su, 2013). In the "one size fits all" approach to learning each student in every cohort of students is given access to the same learning objects in the same way as every other student who is studying the same course. The learning objects or learning content stays static regardless of the learning requirements of different students.

The objective of Adaptive Educational Hypermedia Systems (AEHS) is to afford learners the opportunity to engage with learning content which has been specifically designed to meet the learning requirements of each individual learner by adapting the content and the user interface to suit the needs of a specific user. AEHS could be used in the education of learners at all stages of their education from junior school to post graduate level. AEHS could also be used in organisations for continuous professional development or training for compliance purposes, for example, first aid or manual handling. Software engineering for AEHS commences with a thorough study of the requirements of the proposed system. AEHS, as proposed systems, are very complex systems to design as the software engineer has to design a system to enable non-technical and technical educator authors to design adaptive learning courses for use by students. Therefore, the design and development of AEHS are very complicated, time consuming, and expensive. This article reviews a few of the challenges encountered in the design and development of these complex systems and some of the challenges encountered by educators who propose to use AEHS with their students.

The background section of this article provides the reader with brief definitions and discussions on the concept of AEHS and positions AEHS in the larger research area of E-Learning or Technology Enhanced Learning. The main body of the paper outlines some of the challenges encountered in the development and use of AEHS including: the classification of different categories of learners; the sourcing of suitable educational materials or learning resources; gauging the impact that AEHS have on the learning experience of end users; and student access to open and editable user models/ profiles. Followed by sections on the following: solutions and recommendations; future research directions and the conclusion.

\section{BACKGROUND}

"Adaptive hypermedia systems build a model of the goals, preferences and knowledge of each individual user, and use this model throughout the interaction with the user, in order to adapt to the needs of that user" (Brusilovsky, 2001, p. 87). AEHS build a model of each individual student, and use the information from this model to determine the adaptive learning experiences to be created for each student. 
The following sections provide more information on AEHS and include definitions of the terms Adaptive Education (AE), Adaptive Educational Hypermedia (AEH) and Adaptive Educational Hypermedia Systems (AEHS). E-learning and Technology Enhanced Learning (TEL) pertain to various forms of teaching and learning through the use of technology (O'Donnell \& O'Donnell, 2015) and access to the Internet. TEL in the context of this article can be used synonymously with E-Learning. AEHS is a form of E-Learning which goes beyond the "one size fits all" approach to E-Learning by adapting the content to suit the learning requirements of individual learners.

\section{Adaptive Education (AE)}

Adaptive Education (AE) can be defined as an educational experience that adapts to suit the learning requirements of each individual learner. The purpose of $\mathrm{AE}$ is to provide learners with learning resources which have been specially selected to suit their specific learning needs.

\section{Adaptive Educational Hypermedia (AEH)}

AEH is electronic content which can be used in the provision of adaptive education. Software developers and educational providers are continuously exploring how technology can be used to enhance the learning experience of students.

In a study of AEH authoring tools, Gaffney, Staikopoulos, O' Keeffe, Conlan, and Wade (2014) suggest that "AEH authoring tools have however not been as successfully adopted as was initially expected" (p. 416). Further research is required to explore why AEH authoring tools have not been as successfully adopted as initially expected.

\section{Adaptive Educational Hypermedia Systems (AEHS)}

Adaptive Educational Hypermedia Systems (AEHS) are designed and developed to deliver adaptive educational experiences to students. Some examples of AEHS include: GRAPPLE (De Bra et al., 2012; Glahn et al., 2011); AHA! (De Bra, Stash, Smits, Romero, \& Ventura, 2007; Knutov, De Bra, \& Pechenizkiy, 2009); and ELM-ART (Weber \& Brusilovsky, 2001). AEHS use many different mediums of electronic content. Hypertext is a section of online text or an online paragraph of information that has been embedded with links to other content. Hypermedia is electronic content which includes links to many different mediums of content as shown in Figure 1, such as: text; images; tables; figures; graphics; audio; video; animations; simulations; or games.

Figure 1. Hypermedia can be linked to many different mediums of content

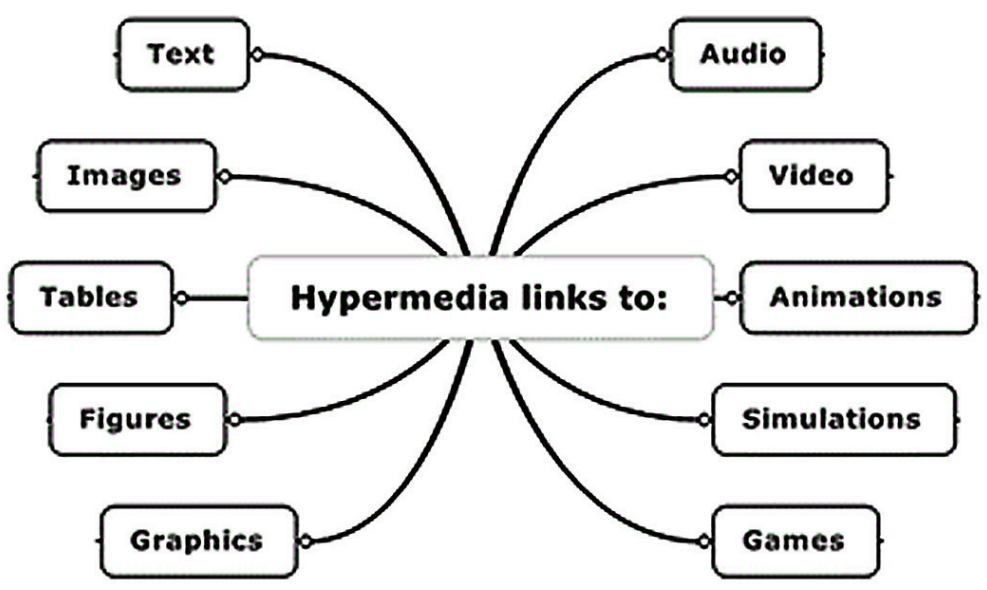


The purpose of AEHS is to provide educators with the appropriate toolset to present learners with educational resources that have been specifically selected to suit their individual learning requirements. AEHS or Adaptive Hypermedia Systems for Education (AHSE) have the potential to facilitate personalised technology enhanced learning (Muntean \& McManis, 2004). AEHS Authoring Tools (ATs) are created to enable non-technical educator authors to design and create adaptive learning resources.

\section{CHALLENGES ENCOUNTERED IN THE DEVELOPMENT OF AEHS}

The development of AEHS is a very difficult process (Baig, 2014). There are many challenges to consider when designing these systems. A few of the challenges are outlined in this paper but others doexist. AEHS are very complex systems because they are designed to be used by many educators and many students who will possess various different knowledge levels of the use of Information and Communications Technology (ICT). There are numerous considerations and challenges involved in designing and developing systems for use by non-technical authors. There are also several challenges involved in developing systems for use by technically competent authors who may require the affordance of complicated functionality. In addition, the designers and developers of AEHS have to meet the challenges of facilitating the functionality required by educators who employ various different pedagogical teaching methods (O’Donnell, Lawless, Sharp, \& Wade, 2015) and learning theories (O’Donnell, Lawless, Sharp, \& O’Donnell, 2015).

Adding adaptive functionality to an educational system does not necessarily improve the system, sometimes the adaptive functionality can cause users to lose control of the system (Brusilovsky, 1996). Adding adaptive functionality to an existing Learning Management System (LMS) does not necessarily improve the students' learning experiences. The students may not understand why they are getting access to different learning experiences to those of their peers. And, the educators may lose control over the adaptive functionality resulting in the students not achieving the expected learning outcomes.

Instructional designers and academics require a number of skills to develop positive learning experiences (O'Rourke \& Martin, 2011). As shown in Figure 2, some of these required skills may include: pedagogical knowledge (Hirumi, Appelman, Rieber, \& Van Eck, 2010; Koh \& Chai, 2014); critical and creative thinking (Baum \& Newbill, 2010); knowledge of instructional development (Stes, Coertjens, \& van Petegem, 2010); awareness of aesthetic principles (Yanchar \& Gabbitas, 2011); experience in instructional design (van Rooij, 2010); competence in the use of ICT(O’Rourke \& Martin, 2011); among others.

Figure 2. Some of the skills required to develop positive learning experiences

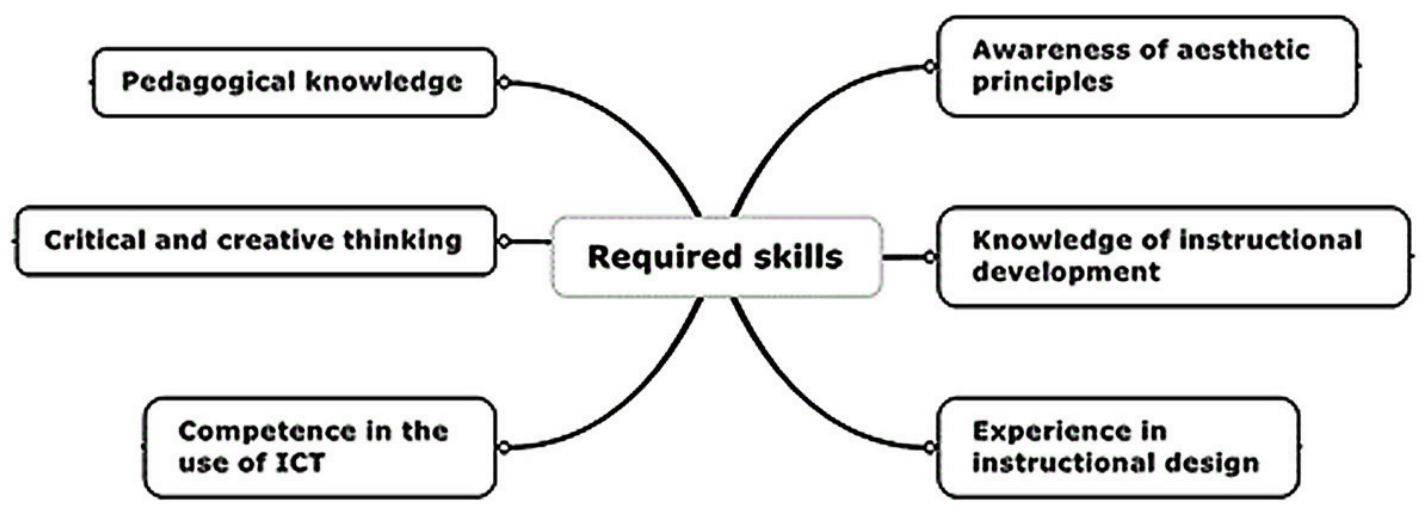


Figure 3. Some of the student characteristics that can be used to classify different types of learners

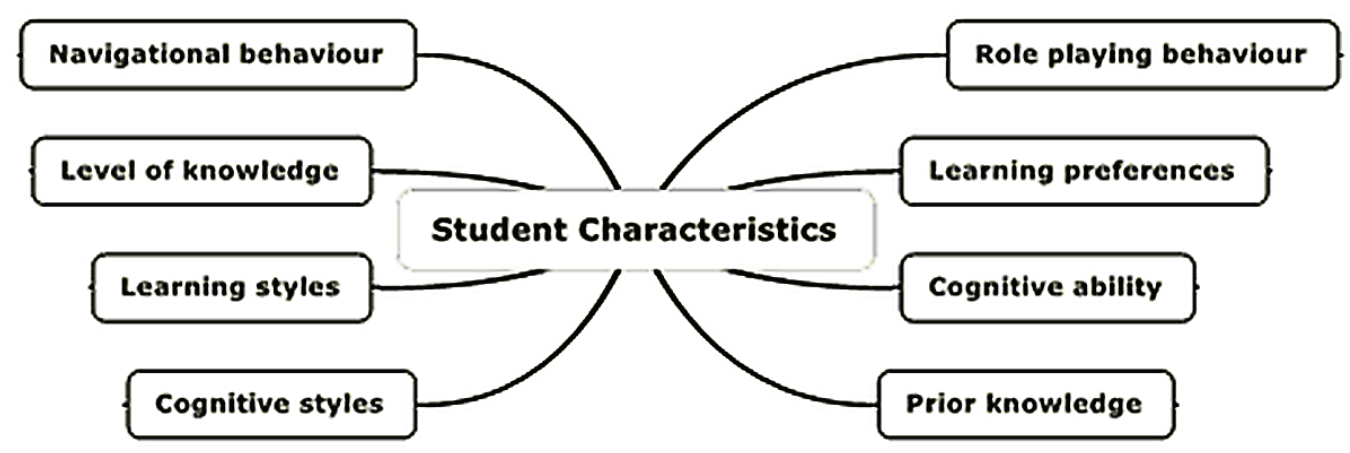

The skill set required and the challenges encountered will markedly increase as instructional designers attempt to develop positive learning experiences that are also adaptable to each learner's specific learning requirements.

The use of AEHS to support learners can pose challenges to learners with respect to cognitive load and self-regulated learning, Moos (2014) and Kuo and Huang (2009) proposed the use of scaffolding in the development of AEHS to support learners. In the design and development of AEHS both the academic users and the student users (learners) have to be considered and facilitated. This dual requirement increases the complexity in designing and developing AEHS.

\section{The Classification of Different Categories of Learners}

Classification of learners is necessary to inform adaptive E-Learning models (Musumba, Oboko, \& Nyongesa, 2013). User profiles (Brusilovsky \& Millan, 2007) are necessary to store the information collected on each user. Profiling the learners' present knowledge informs academics about the gaps in knowledge and the level at which this information should be focused (Ajmal, Hamidullah, Rahman, \& Khan, 2011).

Classification can be based on various different student characteristics as outlined in Figure 3, including the following: level of knowledge (Musumba et al., 2013); learning styles (Akbulut \& Cardak, 2012); cognitive styles (Lo, Chan, \& Yeh,
2012); prior knowledge (Chen, Chen, \& Sun, 2014; O'Donnell, Sharp, Wade, \& O'Donnell, 2012); learning preferences (O'Donnell et al., 2012); cognitive ability (O'Donnell et al., 2012); navigational behaviour (Brusilovsky, 2007; O' Donnell et al., 2012); role playing behaviour (Peeters, Bosch, Meyer, \& Neerincx, 2014); among others.

\section{The Sourcing of Suitable Educational Materials or Learning Resources}

Another challenge encountered in the development of AEHS is the identification of suitable learning resources or objects to be used in the system. Learning objects would also have to be classified to enable retrieval and reuse by AEHS. While educational materials are frequently made available freely online, these resources are available in a number of different formats and may not be easily adopted for use in AEHS. The sourcing of suitable learning resources to facilitate the creation of Adaptive Hypermedia Systems is labour intensive (Levacher, Lawless, \& Wade, 2014) and sometimes it is simply not possible to identify appropriate learning resources to use. The creation of learning resources for use in adaptive systems is a time consuming and complex process (Nurjanah \& Davis, 2012), labour intensive and expensive. A research study conducted by O'Donnell(2008) was undertaken to establish lecturers views on the use of ICT in higher education. The study participants were lecturers from various disciplines within the Dublin Institute of Technology. 41 lecturers 
participated in this study. One of the findings was that only $15 \%$ of the lecturers surveyed agreed that they had sufficient time to create E-Learning resources (O'Donnell, 2008).

\section{Gauging the Impact That AEHS Have on the Learning Experience of End Users}

It is very difficult to state the impact that adaptive systems have had on the learning experience of the end user (Mulwa, Lawless, Sharp, ArnedilloSanchez, \& Wade, 2010; Mulwa, Lawless, Sharp, $\&$ Wade, 2012) and "the jury is still out as regards evidence that ICT supports learning" (Livingstone, 2012, p. 19). The findings of Griff and Matter (2013) from the evaluation of LearnSmart (an adaptive online learning system) was that it had no overall effect. Because it is very difficult to gauge the impact that adaptive systems have had on the learning experience of the end users it may be challenging to encourage more educators to engage with the time consuming task of creating courses using AEHS.

There is a need through controlled evaluations of adaptive technologies to gauge the value added to improving student learning (Shute \& ZapataRivera, 2012). Brusilovsky, Karagiannidis and Sampson (2004) proposed a layered evaluation approach be used when evaluating adaptive learning systems. Until AEHS are used in mainstream education the full impact of adaptive courses on the learning experience of students cannot be evaluated. Further investigations are necessary to gauge the impact that adaptive systems have on the learning experience of end users (learners, students, trainees, employees).

\section{Student Access to Open and Editable User Models/Profiles}

Adaptive systems gather some of the data to be stored in the user model by tracking a user's engagement with the adaptive system (Brusilovsky et al., 2008). Some adaptive systems automatically update the user model so that the user never sees the changes made to their personal user model. In addition, in some adaptive systems users are not given the opportunity to edit their own personal user model for fear it will interfere with the personalisation processes of the system. Ahn, Brusilovsky and Han (2015) state that many arguments have been presented "in favour of open and editable user models" (p. 202).

Another challenge to the developers of AEHS is whether or not to provide the functionality to afford educators the opportunity to enable the users to see and edit their own user model. Some educators may be in favour of allowing their students to see and edit their own user model, while others may prefer to keep control of the user models through system generated automatic updates. In a study of self-regulated personalised learning, Steiner, Nussbaumer, and Albert (2009) found that "Up until now, the structures and algorithms underlying personalisation have been completely kept back from the user. The learner is completely unaware of the personalisation process that is taking place behind the scenes..." (p. 650).

In a survey of forty academics conducted by O'Donnell, Sharp, Wade and O'Donnell (2012) in response to the question "Would you trust the decision making algorithms in an authoring tool to determine the most suitable learning activities for each individual student?" (p. 9), only $10 \%$ of the academics surveyed responded "yes" to this question. Further along in the same study, O’Donnell et al state "The fact that only $10 \%$ of academics surveyed would trust the decision making algorithms is a finding of statistical significance that requires further investigation" (O'Donnell et al., 2012, p. 16). If academics find it hard to trust the decision making algorithms there is a possibility that learners would also like more information about the structures and algorithms used to determine the personalisation process.

Ashman, Brailsford, Cristea, Sheng, Stewart, Toms and Wade (2014) suggest that users should be informed about the personal information that is being collected and how this information is 
Figure 4. AEHS are complex systems to design and develop

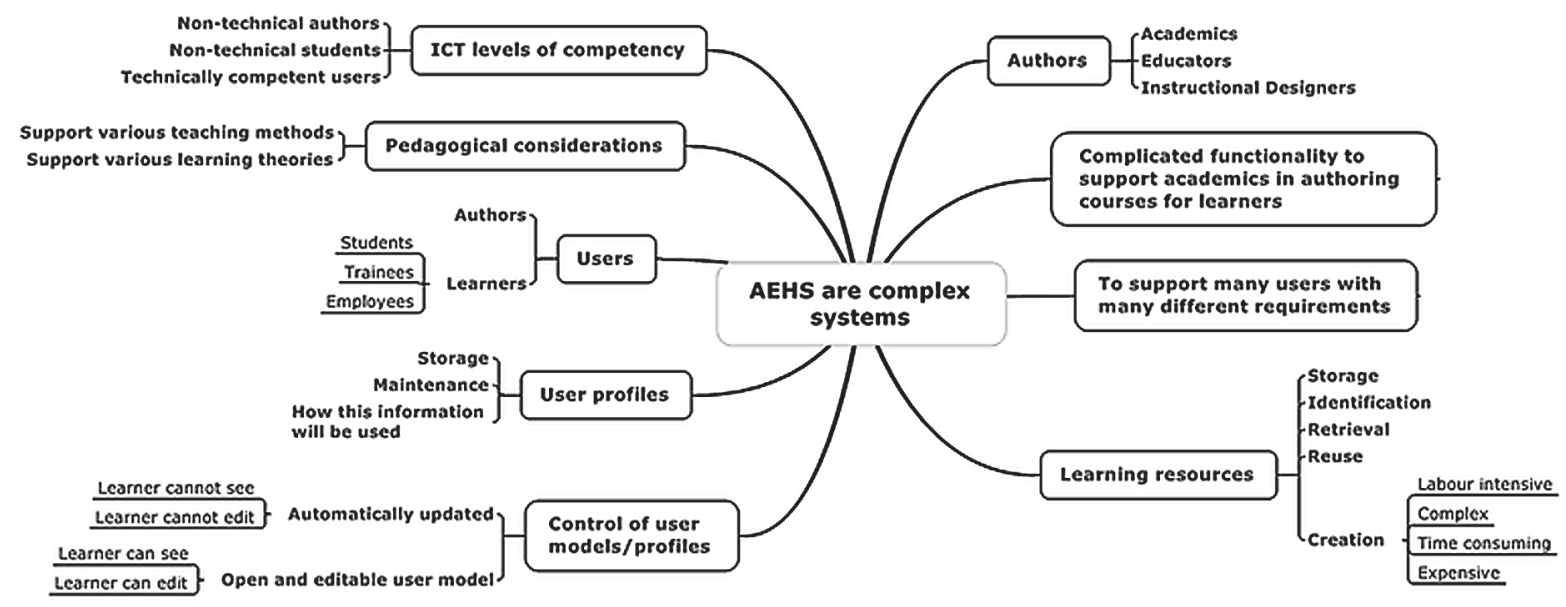

used in educational and other settings. In a study conducted by Staikopoulos, O'Keeffe, Rafter, Walsh, Yousuf, Conlan and Wade (2014), 30.6\% of the students surveyed wanted more control over the content selected by the personalised course.

The amount of control to be allocated to the user of the personalised systems (Parra-Santander $\&$ Brusilovsky, 2015) and the right of the user to edit their own user model (Ahn et al., 2015) pose further challenges in the design and development of AEHS. The amount of control allocated to the user and the right of the user to edit their user model require further investigation to establish some guidelines for those challenged with the development of AEHS. AEHS are complex systems to design and develop and present many challenges as illustrated in Figure 4.

\section{SOLUTIONS AND RECOMMENDATIONS}

Designers and developers of AEHS require further feedback from the academic community and student body to inform future developments of AEHS authoring tools. Instructional designers and developers of E-Learning courses require additional supports and encouragement to engage with AEHS authoring tools. Further evaluations of existing adaptive courses are required to gauge the impact that adaptive courses have on the learning experience of students to inform the designers and developers of AEHS and the educators who design and develop adaptive courses.

\section{FUTURE RESEARCH DIRECTIONS}

Further research is required to explore why AEH authoring tools have not been as successfully adopted as initially expected. AEHS are not yet sufficiently developed for use by non-technical authors. Further work is required on the development of AEHS. Further investigations are necessary to gauge the impact that adaptive systems have on the learning experience of end users (learners, students, trainees and employees). Further investigations are also required into the amount of control that should be allocated to the end user, and the right of the user to see and edit their user model/profile.

\section{CONCLUSION}

AEHS are very complex systems to design and develop. While the concept of AEHS is very promising, the realisation is very challenging, expensive, and time consuming. Some educators feel that they have insufficient time to engage in 
the creation of e-learning resources while others feel that they could not trust the decision making algorithms which determine the most suitable learning resources to present to each student. The challenges encountered in the development of AEHS are many and varied as outlined in this paper. Further research is necessary to investigate the true potential of AEHS.

\section{REFERENCES}

Ahn, J., Brusilovsky, P., \& Han, S. (2015). Personalized search: reconsidering the value of open user models. Paper presented at the 20th International Conference on Intelligent User Interfaces, Atlanta, GA. doi:10.1145/2678025.2701410

Ajmal, M., Hamidullah, H., Rahman, F., \& Khan, B. (2011). Course book evaluation through instructional design parameters in the system of distance education. International Journal of Academic Research, 3(1), 638-644.

Akbulut, Y., \& Cardak, C. (2012). Adaptive educational hypermedia accommodating learning styles: A content analysis of publications from 2000 to 2011. Computers \& Education, 58(2), 835-842. doi:10.1016/j.compedu.2011.10.008

Ashman, H., Brailsford, T., Cristea, A., Sheng, Q., Stewart, C., Toms, E., \& Wade, V. (2014). The ethical and social implications of personalization technologies for e-learning. Information \& Management, 51(6), 819-832. doi:10.1016/j. im.2014.04.003

Baig, F. (2014). Quality assessment of COFALE: An authoring tool for Adaptive Educational Hypermedia Systems. Journal of Quality and Technology Management, X(11), 95-108.

Baum, L., \& Newbill, P. (2010). A journey through a Jamestown-Era native American village. TechTrends, 54(5), 27-37. doi:10.1007/ s11528-010-0434-z
Brusilovsky, P. (1996). Methods and techniques of adaptive hypermedia. User Modeling and UserAdaptedInteraction, 6(2-3), 87-129. doi:10.1007/ BF00143964

Brusilovsky, P. (2001). Adaptive hypermedia. User Modeling and User-Adapted Interaction, 11(1/2),87-110. doi:10.1023/A:1011143116306

Brusilovsky, P. (2003). Developing Adaptive Educational Hypermedia Systems: from Design Models to Authoring Tools. In T. Murray, S. Blessing, \& S. Ainsworth (Eds.), Authoring Tools for Advanced Technology Learning Environments (pp. 377-410). Dordrecht: Kluwer Academic Publishers. doi:10.1007/978-94-017-0819-7_13

Brusilovsky, P. (2004). Knowledge Tree: A distributed architecture for adaptive e-learning. Paper presented at the International World Wide Web Conference - 13th international www conference - Session: Adaptive e-learning systems, New York, NY.

Brusilovsky, P. (2007). Adaptive navigation support. In P. Brusilovsky, A. Kobsa, \& W. Nejdl (Eds.), The adaptive web (pp. 263-290). Berlin: Springer-Verlag. doi:10.1007/978-3-540-720799_8

Brusilovsky, P., Karagiannidis, C., \& Sampson, D. (2004). Layered evaluation of adaptive learning systems. International Journal of Continuing Engineering Education and Lifelong Learning, 14(4/5), 402-421. doi:10.1504/ IJCEELL.2004.005729

Brusilovsky, P., \& Millan, E. (2007). User models for adaptive hypermedia and adaptive educational systems. In P. Brusilovsky, A. Kobsa, \& W. Nejdl (Eds.), The Adaptive Web. Berlin: Springer. doi:10.1007/978-3-540-72079-9_1

Brusilovsky, P., Sosnovsky, S., Lee, D., Yudelson, M., Zadorozhny, V., \& Zhou, X. (2008). An open integrated exploratorium for database courses. Paper presented at the ITiCSE '08, Madrid Spain. doi:10.1145/1384271.1384280 
Chatti, M. A., Jarke, M., \& Specht, M. (2010). The 3P Learning Model. Journal of Educational Technology \& Society, 13(4), 74-85.

Chen, J., Chen, M., \& Sun, Y. (2014). A tag based learning approach to knowledge acquisition for constructing prior knowledge and enhancing student reading comprehension. Computers \& Education, 70, 256-268. doi:10.1016/j.compedu.2013.09.002

De Bra, P., Smits, D., van der Sluijs, K., Cristea, A., Foss, J., Glahn, C., \& Steiner, C. (2012). GRAPPLE: Learning Management Systems Meet Adaptive Learning Environments. In A. Peña-Ayala (Ed.), Intelligent and Adaptive ELS, SIST 17 (pp. 133-160). Berlin: Springer-Verlag.

De Bra, P., Stash, N., Smits, D., Romero, C., \& Ventura, S. (2007). Authoring and Management Tools for Adaptive Educational Hypermedia Systems: The AHA! Case Study. In Studies in Computational Intelligence (SCI) (Vol. 62, pp. 285-308). Berlin: Springer-Verlag.

Gaffney, C., Staikopoulos, T., O’Keeffe, I., Conlan, O., \& Wade, V. (2014). A training framework for Adaptive Educational Hypermedia authoring tools. Paper presented at the Open Learning and Teaching in Educational Communities 9th European Conference on Technology Enhanced Learning, EC-TEL 2014, Graz, Austria. doi:10.1007/9783-319-11200-8_35

Glahn, C., Steiner, C., de Bra, P., Docq, F., O'Donnell, E., Verpoorten, D.,... Stash, N. (2011). GRAPPLE(Generic Responsive Adaptive Personalized Learning Environment): Second empirical evaluation in academic settings. Retrieved from http://ebookbrowsee.net/d9-5-wp9-finalevaluation-v1-0-pdf-d633058884

Griff, E., \& Matter, S. (2013). Evaluation of an adaptive online learning system. British Journal of Educational Technology, 44(1), 170-176. doi:10.1111/j.1467-8535.2012.01300.x
Hirumi, A., Appelman, B., Rieber, L., \& Van Eck, R. (2010). Preparing instructional designers for game-based learning: Part 1. TechTrends, 54(3), 27-37. doi:10.1007/s11528-010-0400-9

Hsieh, T., Lee, M., \& Su, C. (2013). Designing and implementing a personalized remedial learning system for enhancing the programming learning. Journal of Educational Technology \& Society, 16(4), 32-46.

Knutov, E., De Bra, P., \& Pechenizkiy, M. (2009). AH 12 years later: A comprehensive survey of adaptive hypermedia methods and techniques. New Review of Hypermedia and Multimedia, 15(1), 5-38. doi:10.1080/13614560902801608

Koh, J., \& Chai, C. (2014). Teacher clusters and their perceptions of technological pedagogical content knowledge(TPACK) development through ICT lesson design. Computers \& Education, 70, 222-232. doi:10.1016/j.compedu.2013.08.017

Kuo, Y. H., \& Huang, Y. M. (2009). MEAT: An authoring tool for generating adaptable learning resources. Journal of Educational Technology \& Society, 12(2), 51-68.

Levacher, K., Lawless, S., \& Wade, V. (2014). Slicepedia: Content-agnostic slicing resource production for Adaptive Hypermedia. Computer Science and Information Systems, 11 (1), 393-417. doi:10.2298/CSIS121223014L

Livingstone, S. (2012). Critical reflections on the benefits of ICT in education. Oxford Review of Education, 38(1), 9-24. doi:10.1080/03054985. 2011.577938

Lo, J., Chan, Y., \& Yeh, S. (2012). Designing an adaptive web-based learning system based on students cognitive styles identified online. Computers \& Education, 58(1), 209-222. doi:10.1016/j. compedu.2011.08.018

Moos, D. (2014). Setting the stage for the metacognition during hypermedia learning: What motivation constructs matter? Computers \& Education, 70,128-137. doi:10.1016/j.compedu.2013.08.014 
Mulwa, C., Lawless, S., Sharp, M., ArnedilloSanchez, I., \& Wade, V. (2010). Adaptive educational hypermedia systems in technologyenhanced learning: a literature review. Paper presented at the ACM. doi:10.1145/1867651.1867672

Mulwa, C., Lawless, S., Sharp, M., \& Wade, V. (2012). The Evaluation of Adaptive TechnologyEnhanced Learning Systems. Paper presented at the The World Conference on E-Learning in Corporate, Government, Healthcare and Higher Education E-LEARN 2012, Montreal, Quebec, Canada.

Muntean, C., \& McManis, J. (2004). Adaptive elearning systems: Evaluation issues. Transactions on Automatic Control and Computer Science, 49(63), 193-198.

Musumba, G., Oboko, R., \& Nyongesa, H. (2013). Agent-based adaptive e-learning model for any learning management system. International Journal of Machine Learning and Applications, 2(1). doi:10.4102/ijmla.v2i1.6

Nurjanah, D., \& Davis, H. (2012). Improving the workspace awareness of authors in asynchronous collaborative authoring of learning designs. Paper presented at the EdMedia 2012 - World Conference on Educational Media and Technology, Denver, CO.

O'Donnell, E. (2008). Can e-learning be used to further improve the learning experience to better prepare students for work in industry (Masters in Information Systems for Managers). Dublin: Dublin City University. Retrieved from http:// arrow.dit.ie/buschmanoth/1

O'Donnell, E., Lawless, S., Sharp, M., \& O'Donnell, L. (2015). Learning theories: epedagogical strategies for Massive Open Online Courses (MOOCs) in higher education. In E. McKay \& J. Lenarcic (Eds.), Macro-Level Learning Through Massive Open Online Courses (MOOCS). Strategies and Predictions for the Future. doi:10.4018/978-1-4666-8324-2.ch006
O'Donnell, E., \& O'Donnell, L. (2015). Technology-Enhanced Learning: Towards providing supports for $\mathrm{PhD}$ students and researchers in higher education. In Curriculum Design and Classroom Management: Concepts, Methodologies, Tools, and Applications (Vols. 1-3, pp. 242-262). Hershey, PA: Information Science Reference.

O’Donnell, E., Sharp, M., Wade, V., \& O’ Donnell, L. (2012). Academics' views on personalised elearning in higher education. Paper presented at the International Conference on Engaging Pedagogy, Institute of Technology, Blanchardstown, Dublin, Ireland. Retrieved from http://arrow.dit. ie/cgi/viewcontent.cgi $?$ article $=1033 \&$ context $=$ buschmancon

ODonnell, E., Lawless, S., Sharp, M., \& Wade, V. (2015). A review of personalised e-learning: Towards supporting learner diversity. International Journal of Distance Education Technologies, 13(1),22-47.doi:10.4018/ijdet.2015010102

ORourke, S. L., \& Martin, M. (2011). Instructional design of a distance education cultural awareness course to enhance currency and authenticity. British Journal of Educational Technology, 42(5), 875-882. doi:10.1111/j.1467-8535.2010.01103.x

Parra-Santander, D., \& Brusilovsky, P. (2015). User-controllable personalization: A case study with SetFusion. International Journal of HumanComputer Studies, 78, 43-67. doi:10.1016/j. ijhcs.2015.01.007

Peeters, M., Bosch, K., Meyer, J., \& Neerincx, M. (2014). The design and effect of automated directions during scenario-based training. Computers \& Education, 70, 173-183. doi:10.1016/j. compedu.2013.07.039

Shute, V., \& Zapata-Rivera, D. (2012). Adaptive educational systems. In P. Durlach \& A. Lesgold (Eds.), Adaptive Technologies for Training and Education (pp. 7-27). Cambridge University Press. doi:10.1017/CBO9781139049580.004 
Staikopoulos, A., OKeeffe, I., Rafter, R., Walsh, E., Yousuf, B., Conlan, O., \& Wade, V. (2014). AMASE: A framework for supporting personalised activity-based learning on the web. Computer Science and Information Systems, 11(1), 343-367. doi:10.2298/CSIS121227012S

Steiner, C., Nussbaumer, A., \& Albert, D. (2009). Supporting self-regulated personalised learning through Competence-Based Knowledge Space Theory. Policy Futures in Education, 7(6), 645661. doi:10.2304/pfie.2009.7.6.645

Stes, A., Coertjens, L., \& van Petegem, P. (2010). Instructional development for teachers in higher education: Impact on teaching approach. Higher Education, 60(2), 187-204. doi:10.1007/s10734009-9294-х

van Rooij, S. W. (2010). Project management in instructional design: ADDIE is not enough. British Journal of Educational Technology, 41(5), 852-864.doi:10.1111/j.1467-8535.2009.00982.x

Weber, G., \& Brusilovsky, P. (2001).ELM_ART: An adaptive versatile system for web-based instruction. International Journal of Artificial Intelligence in Education, 12, 351-384.

Yanchar, S., \& Gabbitas, B. (2011). Between eclecticism and orthodoxy in instructional design. Educational Technology Research and Development, 59(3),383-398. doi:10.1007/s11423-010-9180-3

\section{ADDITIONAL READING}

Acampora, G., Gaeta, M., \& Loia, V. (2011). Combining multi-agent paradigm and memetic computing for personalized and adaptive learning experiences. Computational Intelligence, 27(2), 141-165.doi:10.1111/j.1467-8640.2010.00367.x
Al-Azawei, A., \& Badii, A. (2014). State of the art of learning styles-based adaptive educational hypermedia systems (Ls-Baehss). International Journal of Computer Science and Information Technology, 6(3), 1-19. doi:10.5121/ijcsit.2014.6301

Arora, A., Raisinghani, M., Thompson, L., \& Leseane, R. (2011). Personality scales and learning styles: Pedagogy for creating an adaptive webbased learning system. International Journal of Online Pedagogy and Course Design, 1(1), 29-49. doi:10.4018/ijopcd.2011010103

Bulu, S., \& Pedersen, S. (2012). Supporting problem-solving performance in a hypermedia learning environment: The role of students prior knowledge and metacognitive skills. Computers in Human Behavior, 28(4), 1162-1169. doi:10.1016/j.chb.2012.01.026

Caravantes, A., \& Galán, R. (2011). Generic educational knowledge representation for adaptive and cognitive systems. Journal of Educational Technology \& Society, 14(3), 252.

Colace, F., Santo, M. D., \& Greco, L. (2014). E-Learning and personalized learning path: A proposal based on the adaptive educational hypermedia system. [iJET]. International Journal of Emerging Technologies in Learning, 9(2), 9-16. doi:10.3991/ijet.v9i2.3211

Cristea, A., \& Ghali, F. (2011). Towards adaptation in e-learning 2.0. New Review of Hypermedia and Multimedia , 17(2), 199-238. doi:10.1080/13 614568.2010 .541289

De Bra, P., Smits, D., van der Sluijs, K., Cristea, A., Foss, J., Glahn, C., \& Steiner, C. (2012). GRAPPLE: learning management systems meet adaptive learning environments. In A. Peña-Ayala (Ed.), Intelligent and Adaptive ELS, SIST 17 (pp. 133-160). Berlin, Heidelberg: Springer-Verlag. 
Glahn, C., Steiner, C., De Bra, P., Docq, F., \& O'Donnell, E. (2010). GRAPPLE (Generic Responsive Adaptive Personalized Learning Environment): Second documentation and training for GRAPPLE users. Retrieved from http:// grapple-project.org/public-files/deliverables/ D9.4-WP9-SecondTrainingReport-v1.1.pdf

Kahraman, H. T., Sagiroglu, S., \& Colak, İ. (2013). Anovel model for web-based adaptive educational hypermedia systems: SAHM(supervised adaptive hypermedia model). Computer Applications in Engineering Education, 21(1), 60-74. doi:10.1002/ cae. 20451

Mahnane, L., Trigano, P., Tayeb, L. M., \& Benmimoun, A. (2011). Designing an adaptive hypermedia system based on the use of psycho pedagogical criteria. [IJCSI]. International Journal of Computer Science Issues, 8(2), 669-677.

Mampadi, F., \& Mokotedi, A. P. (2012). Towards effective combination of prior knowledge and cognitive styles in adaptive educational hypermedia systems. [iJET]. International Journal of Emerging Technologies in Learning, 7(3), 11-18. doi:10.3991/ijet.v7i3.2079

Medina-Medina, N., Molina-Ortiz, F., \& GarcíaCabrera,L. (2011). Adaptation and user modeling in hypermedia learning environments using the SEM-HP model and the JSEM-HP tool. Knowledge and Information Systems, 29(3), 629-656. doi:10.1007/s10115-010-0357-1

Mulwa, C., Lawless, S., Ghorab, M. R., O’Donnell, E., Sharp, M., \& Wade, V. (2011). A framework for the evaluation of adaptive information retrieval systems through implicit recommendation. In S. Andrews, Polovina, S., Hill, R. and Akhgar, B. (Ed.), Proceedings of the International Workshop on Task Specific Information Retrieval, TSIR 2011, at the 19th International Conference on Conceptual Structures (Vol. 6828/2011, pp. 366-374). University of Derby, England: Springer.
O'Donnell, E., Mulwa, C., Sharp, M., \& Wade, V. (2013). Web-mediated education and training environments: a review of personalised interactive e-learning resources. In E. McKay (Ed.), ePedagogy in Online Learning: New Developments in Web Mediated Human Computer Interaction. Hershey, New York: IGI Global. doi:10.4018/9781-4666-3649-1.ch012

O'Donnell, E., Sharp, M., Wade, V., \& O'Donnell, L. (2013). Challenges encountered in creating personalised learning activities to suit students learning preferences. In Y. Kats (Ed.), Learning Management Systems and Instructional Design: Best practices in online education (pp. 263-287). Hershey, Pennsylvania, USA: IGI Global. doi:10.4018/978-1-4666-3930-0.ch014

O’Donnell, E., Sharp, M., Wade, V., \& O’ Donnell, L. (2014). Personalised e-learning: the assessment of students' prior knowledge in higher education. In V. Wang (Ed.), Handbook of research on education and technology in a changing society. Hershey, New York: IGI Global. doi:10.4018/9781-4666-6046-5.ch055

Somyürek, S. (2015). The new trends in adaptive educational hypermedia systems. International Review of Research in Open and Distance Learning, 16(1). doi:10.19173/irrodl.v16i1.1946

Souhaib, A., Mohamed, K., Kamal Eddine, E. K., $\&$ Ahmed, I. (2010). Adaptive hypermedia systems for e-learning. [iJET]. International Journal of Emerging Technologies in Learning, 5(SI3), 47-51. doi:10.3991/ijet.v5s3.1287

Steiner, C., Hillemann, E., Verpoorten, D., Kleinermann, F., Pekczynski, P., \& O’Donnell, E. (2010). GRAPPLE (Generic Responsive Adaptive Personalized Learning Environment): Refinement and improvement of evaluation guidelines. Retrieved from http://www.grapple-project.org/ public-files/deliverables/D8.2b-WP8-EvaluationGuidelines-v1.0.pdf 
Yang, J., Huang, Z. X., Gao, Y. X., \& Liu, H. T. (2014). Dynamic learning style prediction method based on a pattern recognition technique. IEEE Transactions on Learning Technologies, 7(2), 165-177. doi:10.1109/TLT.2014.2307858

\section{KEY TERMS AND DEFINITIONS}

Adaptive Education (AE): The purpose of Adaptive Education (AE) is to provide learners with learning resources that have been specially selected to suit the specific learning requirements of each individual.

Adaptive Educational Hypermedia (AEH): Electronic content which is used in the provision of adaptive education.

Adaptive Educational Hypermedia Systems (AEHS): Systems that provide educators with the appropriate toolset to present learners with educational resources that have been specifically E selected to suit their individual learning requirements. AEHS are designed and developed to deliver adaptive educational experiences to students.

E-Learning: Facilitating teaching and learning through the use of technology and access to the Internet.

Hypermedia: Electronic content which includes links to many different mediums of content, such as: text; tables; figures; graphics; images; audio; video; animations; simulations; interactive games.

Hypertext: A section of online text or an online paragraph of information that has been embedded with links to other content.

Technology Enhanced Learning (TEL): Learning which is enhanced through the use of technology and the Internet. 